\title{
Mainstreaming Gender in Karāchī’s Public Transport Policy
}

\author{
Neha Panjwani ${ }^{1}$
}

\begin{abstract}
Conversations around gender inequality often focus on access to health, education, and workplace rights, but scarcely concern the transportation sector. The latter is highly gender discriminatory, especially in developing countries such as Pakistan, affecting the mobility of women and third genders, who face inequities in the provision and accessibility of this public service. Such constraints to safe, efficient, and comfortable mobility create serious problems for certain genders reflecting their economic security: this by extension is both a cause and an effect of social inequality, and the failure of federal budget allocation towards transportation leading to profound gender disparities in cities. It not only affects mobility but also, consequently, shapes the way in which space is occupied by women in public spheres. In the light of these challenges, this policy paper seeks to highlight the specific mobility challenges faced by women and transgender population, in the metropolis of Karāchī, who commute via public transport that includes buses, taxis and rickshaws. It highlights existing shortcomings in, and recommends an urgent focus on a more inclusive, need-based public transportation system. By drawing on the principles of gender mainstreaming interventions in public transportation in other countries, and data from first-hand interviews with local conductors, bus drivers and passengers - this policy makes some pragmatic recommendations, paying special attention to issues of inclusion, accessibility, safety and mobility. The implications of this study are to enhance evidence-based policy-making in transportation with particular focus on urban planning and gender - sensitive city development.
\end{abstract}

\section{What is Gender Mainstreaming?}

To introduce gender-inclusive transport policies, it is important to understand what 'gender mainstreaming' is. 'Gender mainstreaming' was defined by the United Nations Economic and Social Council (ECOSOC) in 1997 as "a strategy for making women's as well as men's concerns and experiences an integral dimension of [...] the policies and programs in all political, economic and societal spheres so that women and men benefit equally and inequality is not perpetuated." (The World Bank, March 2010). While this definition serves to recognize the transport needs of women, it still discriminates on the basis of gender by operating on the dualistic binary of man and woman, and outright excluding transgender people or other gender variant identities who do not identify themselves in either of the defined gender categories.

It is reasonable to think that some countries face a challenge in aligning their policies with gender mainstreaming recommendations owing to the lack of knowledge regarding mainstreaming and limited understanding of the structural strategies in the policy-making process. Addressing this difficulty, the International Labor Organization (ILO) states, "Mainstreaming is not about adding a "woman's component" or even a "gender equality component" into an existing activity. It goes beyond increasing women's participation; it means bringing the experience, knowledge, and interests of women and men to bear on 
the development agenda." (International Labor Organization, n.d.). This definition points toward the active involvement and participation of both, men and women as important stakeholders in the policy's needs-analysis and planning process through disaggregated data collection, proportional representation in policy design as well as labor participation in transport sector.

\section{Mainstreaming Gender in Transport}

Sustainable Development Goal (SDG) Number 11 formulated by United Nations highlights the aim of 'making cities inclusive, safe, resilient and sustainable.' "In order to achieve this general objective, the UN aims, inter alia, to provide access to safe, affordable, accessible and sustainable transport systems and improve road safety for all by 2030 , notably by expanding public transport with special attention to the needs of those in vulnerable situations: women, children, people with disabilities and older people.” (European Institute for Gender Equality, 2017). Recognizing the significance of gender in public transport is rather novel as is evidenced by the fact that United Nations only introduced gender mainstreaming into transport in 2008. The official report highlighted that "little attention appears to have been paid to women's needs in transport development projects worldwide, even though transport can make a major difference in increasing women's productivity and in promoting gender equality" (Ibid). In other words, inaccessibility to sustainable transportation has effects on a woman's economic security and the overall growth of the economy. These adverse impacts of inaccessibility, particularly on their social and economic position are addressed later in the paper.

\section{Five A's of sustainable transportation: Availability, Accessibility, Affordability, Acceptability, and Appropriateness.}

A sustainable and inclusive transportation system is one that is sensitive to all genders, and can be characterized by these five parameters: Affordability, Availability, Acceptability, Accessibility, and Appropriateness. (Thynell, 2016). These parameters will serve as entry points to an analysis of the difficulties faced by women and transgender identities in Karāchīs transportation system. Factors such as acceptability and appropriateness point towards the pressing need to account for social as well as cultural factors in inclusive transportation planning rather than solely physical and monetary factors. Difficulties related to safety and accessibility are identified through first-hand accounts and interviews carried out with commuters.

\subsection{Availability and Accessibility:}

In Karāchī, there are various modes of public transportation including cars, taxis, rickshaws, qingqis ${ }^{1}$ (motorcycles with six-seater carriages attached) buses, and minibuses. However, the supply of these vehicles is disproportional to its increasing demand. Buses often become common targets of ethnic riots and end up getting burnt,

1 "QINGQIs have become a popular mode of public transportation in Karachi owing to its cheap fares, seating capacity and convenience of providing last mile service to passengers. 
yellow taxis are almost extinct, and as a result, rickshaws and qingqis are left as the most popular alternatives to cheap public transport in the city.

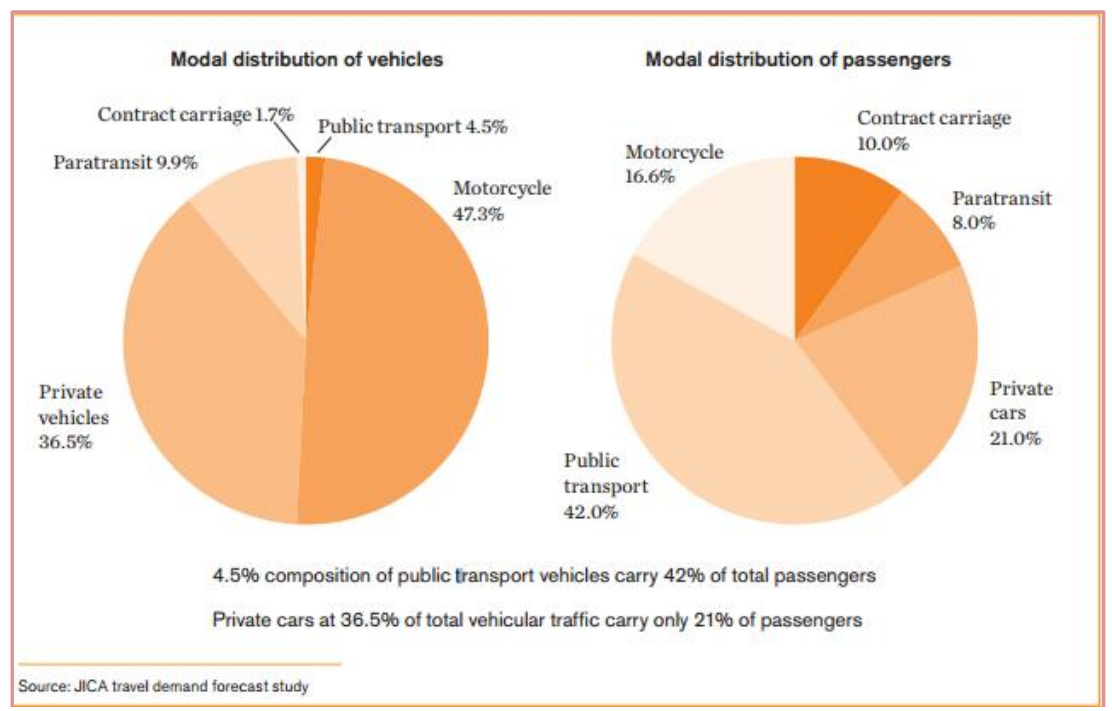

Figure 1. Modal distributions. This figure illustrates the modal distribution of vehicles and passengers highlighting the gap in demand and supply of various transportation modes.

A research study conducted by Urban Resource Centre on Karāchī’s transport crisis reveals the following shortfall in the supply of public buses. "i), internationally accepted ratio is of one 100 -seater bus for a population of 1,500; ii), population of Karāchī 20 million; iii), as such requirement of large buses 13,333; iv), existing equivalent of large size buses in the form of 35 seater minibuses: 4,657; and v), shortfall / immediate requirement for Karāchī 8,676 large buses.” (Hasan, 2015).

Even with the availability of these limited transport choices, there is inaccessibility in terms of transit routes, areas of coverage, time-distance cost, personal safety, and vehicle design. These transport services run mainly within the city's main areas without accounting for the fact that the population using them is mainly of lower economic classes, people who reside mostly in the periphery of the city (in areas such as Moach Goth, Lyari, Port) where such services are inaccessible and scarce. This makes it difficult for them to commute to the city center every day for work, imposing long distances and travel times, often extending up to two hours. For a city that has been growing horizontally and expanding into the peripheries, "the lengths of commutes for the working class are [then] in the range of 20 to 40 kilometers." (Hasan, 2015).

Moreover, from a study conducted in 2015 of a sample size of 150 commuters, it was computed that on average, they spend ". . . approximately 2 hours daily, round trip (624 hours per annum) while commuting, which is much higher than world average commuting hours. According to a study, world average commuting time is 80 minutes, in a day. Thailand is considered to have the longest commuting in the world while Malawi has shortest commuting time. A 2007 Gallup Survey (in USA), indicated that in a typical day, workers' average round trip commute takes 46 minutes. Similarly, according to UK 
Office of National Statistics (2011), 75 percent of the workers take around 1 hour for a round trip from home to work." (Hasan \& Raza, 2015).

Bindiya Rana, a transgender woman and an activist living in Karāchī, mentioned multiple times that "even though we [transgender people] are dispersed in different areas throughout the city, these are mostly places where public transport is not available so we have to cross one or two neighborhoods to reach a bus stop. Most of our time is, hence, spent walking in hot weather." In Pakistan, third genders, particularly speaking transwomen, are popularly known as hijräs or khawäjā sirās (translated: transwoman), although the former term is often considered offensive while the latter demands utmost respect of a community whose roots go back to Mughal Era and ancient Hindu epics. However, today most of these khawäjä siräs' main livelihood comes from begging on streets and multiple traffic signals throughout the city. According to Bindiya, "Many transgender people beg at multiple traffic signals throughout the day to earn more cash so commuting from one traffic signal to another in different areas during day-hours becomes time-consuming taking up most of their precious work hours." (Rana, personal communication, May 13, 2017).

Another important factor, which makes public transport inaccessible for women and transgender communities is personal safety and security, which mainly includes fear of sexual harassment. This is the reason many working women tend to prefer open vehicles such as rickshaws and qingqis over crowded buses and locked taxis where they are at a risk of being called at, groped, bothered, and sexually assaulted. In a survey conducted by Urban Resource Centre on harassment faced by women commuters in public transport, the responses indicated that, "Men in cars and on motorbikes stop and offer them [women] lifts while they are waiting at bus stops. Sometimes this turns into pestering. Men enter into the women's compartment of the bus and refuse to leave when asked to do so. Rickshaw drivers constantly stare at the women passengers while driving. This is made possible because of huge rear view mirrors in the rickshaw which focus more on the passenger than the oncoming traffic at the back." (Hasan \& Raza, 2015).

Besides interviewing transwomen, my preliminary research also included an interview with a small group of drivers and conductors on their behavior towards transgender people who travel by bus. According to testimonies, they are rarely bothered but on rare occasions when the male passengers on bus tease them, "[we] scold them off by saying [you'll] get the bad curse of these hijpās, many a times we also ask these perpetrators to get off the bus" (Panjwani, PB). When the same question was posed to Bindiya Rana, the answers were completely contrary to those of drivers and conductors. She exclaimed that it was the conductors who harassed them [transgender people] by blocking their way and asking questions like "why don't you buy me a cigarette, where do you live, what's your name etc." (Interview transcript, May 13, 2017). She added that "we respond verbally by saying it's none of their business but can't slap them on their face like women do [the concept of a third gender isn't understood by many people in the society who still consider them men and coerce them into physical fights] because it will trigger into a physical fight which will end up injuring us, our clothes will be torn and we wouldn't be able to afford new ones." (Personal communication, May 13, 2017). Even in Bindiya's personal experience with Careem (a ride-sharing service in Pakistan) drivers, she mentioned that "if I were to use Careem to drop me off somewhere and call it again after 
a while to pick me up, the same driver won't pick up the call or respond to the request when he sees it's from the same location where he earlier dropped me." (Interview, May 13, 2017)

Lastly, the design of these vehicles is unfavorable and unfair towards women and transwomen keeping them from accessing safe and convenient transport. The seating capacity available for women is inadequate with only 5-7 seats in the front of the bus as compared to men who occupy the rest of the 40-seater bus. This segregation becomes confusing when transgender people come into the picture not knowing where to sit. Speaking on the gender-biased seating patterns of the public buses she commented that "by making dividers in the bus, we ourselves are creating gender differences in the system but if such a system exists, then there should be a separate section for us [transgender people] as well. She exclaimed, 'We don't mind sitting in either men's or women's section but people do. There are no names allotted to seats then why are we asked to not sit and get up? If [the authorities] have assigned seats to women, then assign some for us as well so that even we can say 'this is our seat, get up?" (Interview, May 13, 2017).

\subsection{Affordability:}

It is important to understand the fare systems of various modes of transportation in Karāchī. “... Buses, minibuses, and qingqis charge on a per-passenger basis, whereas taxis and auto rickshaws are privately hired and charge by the trip. Auto rickshaws have the capacity to carry three people at a time and are privately hired. They are relatively more expensive [average fare starting from Rs. 200 per trip] than buses because the passenger pays the entire cost of the trip. Car taxis are even more expensive and are seldom used by lower-middle-class riders, and almost never by the poor." (Hasan \& Raza, 2015). A common grievance among public commuters is the unavailability of feasible transport options. In Karāchī, an interview with 150 respondents yielded the results that from an average monthly income of Rs. 13, 482, the average monthly spending on transport was Rs, 1,500 (approximately 11\%). (Hasan \& Raza, 2015)

Vulnerable gender groups such as transgender people compromise on either safety or affordability when commuting in the city. If they travel by buses, they are harassed and if they choose rickshaw or taxi, they are charged extra due to discriminatory behavior. According to Bindiya, the amount of time spent on commuting is greater than wage earning, "approximately 4 out of 12 working hours are spent commuting which affects our work hours and daily income." (Interview, May 13, 2017). Upon asking her about transport fares and whether those are influenced by their sexual identity, she mentioned that all the drivers overcharge them just to tease them. "We have to switch 6-8 rickshaws to look for a reasonable fair. But then we give up thinking that the time we are spending negotiating can be spent earning so we end up paying the extra 30-40 Rupees." (Interview, May 13, 2017). She mentioned that the common mode of transit for transgender people is rickshaw and taxi since most of them belong to a lower income group. "Only a handful of us (including myself) can avail [the ride-sharing services] Careem and Uber because we have access to internet and are educated enough to operate these services but what about the poor and unprivileged ones amongst us?" (Interview, May 13, 2017). 


\subsection{Acceptability and Appropriateness}

By acceptability and appropriateness, it is meant the cultural and societal norms that both dictate and hinder some genders' mobility in the city. These factors include but are not limited to permission constraints, social attitudes, dualistic gender-thinking, lack of awareness and training, lack of acceptability and inclusiveness, and male-dominant thinking which altogether makes a transit option inappropriate and unfavorable to use. Despite being given the status of official citizens of the country, transgender people struggle to get access to a service as essential and basic as transport. The dichotomous perception prevalent in the society about gender identity keeps them from becoming accepted into the community and as citizens deserving equal rights. The transport sector remains predominantly a man's profession due to the very cultural norms that stop the women from riding motorbikes here. Talking about their challenges in mobility, Bindya also mentioned that if a woman asks for lift on the road, there are chances she might get one but when we [transgender people] ask a passing car to drop us somewhere, we are shrugged off. Adding to this, she said, 'there's also bias in a sense that me getting out of Careem elicits a different response in people from other transgender people getting out of a rickshaw or bus [sic]. There's no acceptance at all; people themselves construct binaries and give birth to differences and distances in a society." (Rana, Interview, May 13, 2017). She pointed out that people lack the awareness and the training to behave correctly with transgender people. The drivers and conductors lack sensitivity and knowledge to accept us as equal and respectable people in society. "They fail to understand that we [transgender people] are performing a double role, both of man and woman. During the day, we engage in livelihood activities through begging and at night we come home and take care of household work with the day's ridicule revolving in our heads, not letting our minds be at peace. One raises voice when there is hope," she said. "There's no hope at all. They are unable to provide services to women, let alone us." (Rana, Interview, May 13, 2017).

\section{Women-only Transportation Projects}

In many countries including, Japan, Brazil, Egypt, Mexico, India, Belarus and the Philippines, 'pink' solutions have been provided in order to combat cases of sexual harassment, physical aggression and personal safety on vehicles including buses, subways, taxis, rails and vans. In Russia, Mexico, UK, Dubai and Iran, there are womenonly taxis and this is the case in many Muslim countries as well where women and men travel separately on public transport.

Recently in Karāchī, a ride-hailing service for women has been initiated by the name of 'Paxi,' with the aim of curbing sexual harassment on public buses and taxis. But there are problems of affordability and accessibility that this service fails to resolve. "I do feel, though, that such ventures will still not cater to a large number of working women who go out to work daily ... since such women will not be able to afford relatively pricey fares in these private cabs." ("Pink Taxi: Women" 2017). The new service, even though women-exclusive, does not provide affordable services to all classes of the urban 
population, much like Careem and Uber, whose base fare per trip is approximately PKR (Pakistani Rupees) 200. A round-trip would roughly double the fare cost to Rs. 400 which becomes difficult for a lower working-class woman to bear every day.

Another news article reported that the working hours of the women drivers in the Paxi service would be from 7 am till 6 pm (Salim, 2017). Safety and accessibility at night are some of the main concerns of women commuters in Karāchī who fear using public transportation because of sexual harassment. Lack of provision of safe transportation options in the evening hours hinders their work opportunities and affects other social engagements resulting in restricted movement in the city.

Contrary to the view reflected in the article that a separate taxi service is an effort at 'empowering' women, (Ibid.) such pink solutions in fact ". . . reinforce the gender order and perpetuate divisions and differences between the sexes rather than comprehensively addressing the deep-rooted gender biases inherent in current transport planning and policy making." (Thynell, 2016, p.76). While these may seem a step forward in making public transportation inclusive and safe, the separation of the two genders are a 'throwback in the fight for women's equal access to public transportation' (Babinard, 2011) and works against the purpose of mainstreaming gender, and social integration.

\section{Adverse Impacts on Economic and Social Lived Experience}

Gendered discrimination in transport and mobility has adverse impacts on vulnerable populations of women and trans-people in various ways: Some of these impacts interconnect and even perpetuate each other:

- Economic growth (includes employment/labor opportunities and the resultant income gap between men and women in the economy)

- Social exclusion (lack of accessibility to services, civic and economic activities due to mobility and cultural constraints)

- Women disempowerment (caused by social isolation and lack of economic output)

- Poverty (perpetuated by all of the above, not just of individual but also the overall economy)

The impacts of women's restricted mobility on economic growth is evident from the fact that "International Labour Organization (ILO) says only a fifth of Pakistan's women have paid jobs because of lack of transportation." (Shah, 2015). A source within the same article mentions that "women workers spend almost half their salaries on transportation while their male colleagues spend only 5 percent. This transportation apartheid results in just 2 percent of adult women having bank accounts and only 15percent workforce inclusion.” (Ibid.). A report by Asian Development Bank (ADB) also identified the lack of access to safe transport as a particular constraint to women's labor force participation in Pakistan (2015). Not only this, it also affects both women and transgender people by restricting their ability to access basic services and amenities such as health clinics and commercial stores, and hinders opportunities of all nature be it employment, education or social, which would otherwise lead to their empowerment and enable them to feel included and independent in society. All the above factors constrain their ability to increase their economic productivity and incomes, keeping them isolated and perpetuating the cycle of poverty. "As a result, constraints on the mobility patterns 
of women [and transgender people] not only affect their household but also the development and productivity of economies as a whole." (The World Bank, 2010).

\section{Current Policy Framework}

At present, there is no National Transportation Policy along the lines of which the provinces can align their transport development plans and functions. Perhaps this is the reason transportation, despite being one of the most significant factors for an economy and country's development has been neglected in Pakistan for the past few decades. A two-year plan for formulating the National Transportation Policy was initiated earlier this year and is supposed to be completed by 2019. In an interview with The News, Joanna Reid, Head of DFID Pakistan, said that "The new (national transport) policy should work for all Pakistanis including women and girls and it should be climate smart to truly meet Pakistan's Vision 2025.” (Haider, 2017).

Ineffective and negligent efforts have been made to align the country's gender policies with the transport department as is evident from one such example. The Government of Pakistan formulated the Gender Reform Action Plan (GRAP), with the help of The Asian Development Bank's Decentralization Support Program to systematically mainstream gender at the federal and provincial levels. This program was approved by the Government of Sindh in 2004 after which mainstreaming cells were established in eleven key departments throughout the administration ("Gender Action Plan", n.d.). However, the source did not specify what these departments were and whether it included the transportation and communication department which manages all transport-related services. Moreover, neither were the functions and operations of the mainstreaming cells clearly established.

\section{Recommendations}

- The first step to mitigating a problem is identifying its root causes. Hence, the government should set up surveillance databases on every transportation vehicle in order to monitor sexual harassment instances and the factors which perpetuate these behaviors in vehicles, be it infrastructural design owing to less seating capacity and overcrowding, or male behavior, lack of lighting, or poor security.

- Provide training and awareness to transport owners, drivers, conductors and staff on sexual harassment, enabling them to promote a safer environment in vehicles.

- Provide them with the tools and materials to document, report, respond to and prevent cases of sexual harassment on their vehicles. Giving them the responsibility of ensuring a sexual harassment free environment might make them less of perpetrators themselves.

- Have the conductor responsible for playing the role of an inspector as well ensuring that the seats assigned for women are available for them only in order to minimize unnecessary interaction eliminating sexual advances on vehicles.

- Give women and transgender people rights based education because often they are harassed and they do not know for sure if the experience warrants a report. This education would enable and empower them to promote a more open and accountable environment. 
- Since in many cases, overcrowding triggers cases of sexual harassment more buses should be introduced and frequency of routes should be increased in order to counter the problem.

- There's a common assumption that transport patterns are uniform across all genders leading to the introduction of services that are biased against some. It is imperative to collect disaggregated data of each gender's transportation and mobility patterns through user surveys in order to account for more informed policies. Refer to table 1 for a proposed questionnaire of data collection.

Table 1. Suggested questionnaire for the collection of disaggregated data.

How do you identify yourself? Male, Female, Trans, Other.

Which age group do you fall under? 15-17, 18-20, 21-30, 31-40, 40-60, 60 and over.

Which geographical area do you reside in?

Which modes of transport do you use the most?

What forms of public transportation are accessible from your location?

What is the frequency of the services which you use daily?

How many round trips do you take per day?

What's the nature of these trips?

Are your trips within peak working hours or off-rush hours i.e. after $6 \mathrm{pm}$ ?

What's your nature of employment (formal, informal) and what's the location of the workplace?

How many paid jobs are you working per day?

How many hours a day do you spend commuting?

Approximately how much of your income is spent on transport related expenses in $\%$ ?

Is your choice of transit mode different in the evening hours? If yes, which one is it?

Would you feel safe if cameras are installed on the vehicles?

How often do you face harassment on public transport? Almost daily, sometimes, once, never?

How do you react to it? Verbal, Physical, Ignore

Has it influenced you to change your mode of transit/route?

Has harassment led you to forego/leave employment, education opportunities that require commuting longer distances/inflexible hours?

Table 2. Interview Questionnaire (Bindiya Rana)

Introductory

Which mode of transit do you usually use?

What times of the day do you mostly travel?

How many trips do you take a day?

What kind of trips?

What is your daily route like?

Your experience of travelling in public transport:

Where do you sit inside the bus and why?

Have you faced any harassment on vehicles? What kind.

How are you treated by staff? (conductors and drivers)

How are you treated by other passengers on vehicle?

How often do you face harassment? 
How do you respond to it?

Does it make you feel hesitant to travel then?

Do you feel the difficulties in transport hinder your movement in the city/work?

Do you know of any transgender people who have similar complaints?

What about fares?

$\underline{\text { Recommendations }}$

Has anyone asked you about mobility challenges before?

Has anyone promised you better transport facilities?

How do you think this problem can be solved?

Do you think there should be a separate compartment for transgender people on the bus?

Have you tried reporting harassment incidents to police?

Will you feel safe if cameras are installed at bus stops and on vehicles?

\section{References}

Asian Development Bank. (n.d.).Gender Action Plan. Retrieved from: https://www.adb.org/sites/default/ files/project-document/63469/41545-02-pak-gap.pdf

Asian Development Bank. (2015). Policy brief: a safe public transportation environment for women and girls. Mandaluyong City, Philippines: Asian Development Bank

Babinard, J. (2011, September 09). New findings on social and physical mobility bring transport into the spotlight again. The World Bank | Transport for Development.

European Institute for Gender Equality. (2017). Transport | EIGE. Retrieved from European Institute for Gender Equality : http://eige.europa.eu/gender-mainstreaming/policy-areas/transport

Haider, Mehtab. (2017, February 9). Govt kicks off project to formulate National Transport Policy. The News. Retrieved from: https://www.thenews.com.pk/print/184986-Govt-kicks-off-project-toformulate-National-Transport-Policy

Hasan, A., \& Raza, M. (2015). Responding to the transport crisis in Karāchī. IIED and Urban Resource Center.

Hasan, A. (2015). Karāchī: The Transport Crisis. IIED and Urban Resource Center.

International Labour Organisation. (n.d.). Definition of Gender Mainstreaming. Retrieved from International Labour Organisation: http://www.ilo.org/public/english/bureau/gender/newsite2002/about/defin.html

Pink taxi: Women-only service to be launched in Karāchī. (2017, March 22). Aljazeera.Retrieved from: http://www.aljazeera.com/news/2017/03/pink-taxi-women-service-launched-Karāchī170322044852165.html

Responding to the transport crisis in Karāchī. (2015). Modal Distributions[Figure]. Retrieved from: bttp://pubs.iied.org/pdfs/10733IIED.pdf

Salim, Yusra. (2017, March 9). Ride-hailing service for women to operate in Karāchī formally from March 23. The Express Tribune. Retrieved from: https://tribune.com.pk/story/1349808/ride-hailingservice-women-operate-Karāchī-formally-march-23/

Shah, Bina. (2015, October 11). TAKEN FOR A RIDE. Newsweek. Retrieved from: http://newsweekpakistan.com/taken-for-a-ride/

The World Bank. (March 2010). Mainstreaming Gender in Road Transport: Operational Guidance for World Bank Staff. Washington: The World Bank.

Thynell, M. (2016). The quest for gender-sensitive and inclusive transport policies in growing Asian cities. Social Inclusion, 4(3). 